\section{Micropropagation of Endemic and Endangered Mexican Species of Ponytail Palms}

\author{
María Luisa Osorio-Rosales ${ }^{1}$ and Martín Mata-Rosas \\ Jardín Botánico Clavijero, Instituto de Ecología A.C. Xalapa, Veracruz, 91070 México
}

Additional index words. Beaucarnea gracilis, Beaucarnea recurvata, Nolinaceae, tissue culture, direct organogenesis, conservation

\begin{abstract}
Experiments were conducted to establish an efficient protocol of micropropagation of Beaucarnea gracilis and B. recurvata two endemic and endangered Mexican species. Multiple shoots were induced by direct organogenesis from in vitro seedlings and longitudinal sections of seedlings in both species. The highest formation of shoots per explant, both $B$. gracilis and $B$. recurvata, was obtained from longitudinal sections of seedlings on Murashige and Skoog (MS) medium supplemented with $22.2 \mu \mathrm{M}$ 6-benzylaminopurine, induced 8.2 and 11.1 shoots per explant respectively. In vitro rooting was readily achieved on MS medium with $1 \mathrm{~g} / \mathrm{l}$ activated charcoal without growth regulators. According to initial treatment and depending on where the shoots come from, the rooting rates were $61 \%$ to $100 \%$ for $\mathrm{B}$. gracilis, and $83 \%$ to $100 \%$ for $B$. recurvata. Survival rates in greenhouse conditions for both species were $80 \%$ to $100 \%$ after 3 months. These results indicate that the micropropagation of these species of Beaucarnea is technically feasible, and that in vitro culture is a useful option for the conservation and propagation of these important endangered species.
\end{abstract}

The Beaucarnea genus is part of the Nolinaceae family, endemic to North America and part of Central America (Eguiarte et al., 1994; Hernández, 1993b;). Beaucarnea distribution extends from southern Tamaulipas, Mexico (near the Tropic of Cancer) to Honduras and probably to northern Nicaragua in CentralAmerica. All species of Beaucarnea (about 10) are considered threatened or endangered. Of these, nine are endemic to Mexico with B. gracilis and $B$. recurvata catalogued as threatened species. (Hernández, 1993a; Semarnat, 2002)

Beaucarnea gracilis Lem. is a tree measuring 6 to $12 \mathrm{~m}$ in height, distributed throughout Mexico's Oaxaca and the Puebla states (Fig. 1a). B. recurvata Lem. reaches 4 to $15 \mathrm{~m}$, and is found in the states of Oaxaca and Veracruz (Fig 1b) (Hernández, 1993b). The wild populations of these two species are threatened as a result of their habitat alteration caused by the opening of areas for agriculture and livestock, as well as by urban expansion and the illegal collection of individuals (Cardel et al., 1997; Franco, 1995; Hernández, 1993a). Both species have great commercial demand as ornamentals, especially $B$. recurvata. Despite the fact that some nurseries are legally propagating Beaucarneas (ponytails), the production and size of the specimens available do not satisfy the national and international market demands, and thus the seeds are constantly and illegally over-collected;

\footnotetext{
Received for publication 1 June 2004. Accepted for publication 10 Apr. 2005. We thank Armando Contreras his support and ideas for the realization of the present research, Joel Flores and Javier Jiménez for their help in the collection of seeds, Victor Chávez for revision of the manuscript and Philip Brewster and Jill Drzewiecki for correcting the English text. Research was supported by the National Council of Science and Technology (CONACyT) 010031 and 37554-N and Instituto de Ecología A.C. 902-10.

${ }^{1}$ To whom reprint requests should be addressed; e-mail osorioml@ecologia.edu.mx.
}

juvenile and adult plantlets are extracted selectively (Hernández, 1993a). This has caused the reduction and even the disappearance of wild populations, which are affected mainly by the reduction of seed production, a phenomenon that influences the size, the population structure, and natural regeneration (Franco, 1995).

In view of the difficulty in achieving efficient in situ conservation for species in this genus, plant tissue culture represents an excellent option for the study and conservation of threatened species, as well as a tool for efficient and fast propagation (Carneiro, etal., 1999; Fay, 1994; González-Benito, et al., 1999; MartínezVázquez and Rubluo, 1989; Mata, et al., 2001a, 2001 b; Mauseth, 1979; Rodríguez-Garay and Rubluo, 1992; Stuppy and Nagl, 1992).

Despite the great worldwide interest for ponytails as ornamentals (in the U.S. mature al., 1997), there are few reports on propagation by tissue culture for $B$. recurvata (Mekers, 1988; Samyn, 1993, 1997) and, as far as we know, there are no reports for $B$. gracilis. The development of viable methods for the propagation of ponytails would thus be beneficial for both commercial and conservation propose. The present study describes the micropropagation of $B$. gracilis and $B$. recurvata from seedlings and longitudinal sections of seedlings germinated in vitro, and their establishment under greenhouse conditions.

\section{Materials and Methods}

Seed germination. Seeds of $B$. gracilis and $B$. recurvata were collected in Puebla and Veracruz (Mexico), respectively. Seeds were washed with a Dawn detergent (Colgate Palmolive, S.A de C.V., Mexico) for $30 \mathrm{~min}$, then sterilized with $70 \%$ ethanol for $1 \mathrm{~min}$, followed by $30 \% \mathrm{v} / \mathrm{v}$ commercial chlorine (sodium hypochlorite, $6 \%$ of active chlorine), plus Tween 80 ( 2 drops/100 $\mathrm{mL}$ ) for $30 \mathrm{~min}$. Seeds were then rinsed three plants may be sold for $\$ 600$ to $\$ 700$ ) (Cardel et times with sterilize, distilled water under aseptic conditions. Finally, the seeds were kept in a solution of Benlate $\left(3 \mathrm{~g} \cdot \mathrm{L}^{-1}\right)$ for $20 \mathrm{~h}$, and subsequently rinsed with sterilize distilled water. Seeds were sown in $125 \mathrm{~mL}$ baby food jars with $25 \mathrm{~mL}$ of Murashige and Skoog MS medium (Murashige and Skoog, 1962), with $2 \mathrm{mg} \cdot \mathrm{L}^{-1}$ glycine; $100 \mathrm{mg} \cdot \mathrm{L}^{-1}$, myo-inositol, and $30 \mathrm{~g} \cdot \mathrm{L}^{-1}$ sucrose (basal MS medium). The $\mathrm{pH}$ was adjusted to 5.7 with $\mathrm{NaOH}$ and $\mathrm{HCl} 0.1 \mathrm{~N}$ before adding $5.5 \mathrm{~g} \cdot \mathrm{L}^{-1}$ agar high gel strength (Sigma Chemical Co., St. Louis, Mo.) and autoclaving at $120{ }^{\circ} \mathrm{C}$ for $15 \mathrm{~min}$. Five seeds were sown per container with 60 repetitions (300 seeds). Cultures were incubated at $25 \pm 1^{\circ} \mathrm{C}$, under a 16-h photoperiod provided by cool-white fluorescent lamps $\left(50 \mu \mathrm{mol} \cdot \mathrm{m}^{-2} \cdot \mathrm{s}^{-1}\right)$. Germination percentages were recorded weekly.

Induction of multiple shoots. Two types of explants were excised from $7 \mathrm{~cm}$ of in vitro-germinated seedlings for both species: a) seedlings with roots and tips of leaves trimmed and placed into culture vertically (Fig. 1c); b) seedlings as above, but dissected in two longitudinal sections and placed into culture with the cut surface in contact with themedium(Fig. 1d). The explants were placed on basal MS medium supplemented with different concentrations of 6-benzylaminopurine (BA) $(0,4.4,13.2$, or $22.2 \mu \mathrm{M})$. Forty explants were used pertreatment, with two explants placed in each jar for 20 repetitions. After the induction period (30 d), monthly subcultures were carried out in basal MS medium, containing $1 \mathrm{~g} \cdot \mathrm{L}^{-1}$ activated charcoal and without growth regulators. The number of shoots per explant was recorded after 3 months.

Rooting of shoots. Regenerated shoots were individualized and subcultured to MS basal medium with $1 \mathrm{~g} \cdot \mathrm{L}^{-1}$ activated charcoal and without plant growth regulators and in order to induce the formation and development of roots. Two months later, rooting was observed and rooting percentage recorded.

Ex vitro survival. The regenerated plants were removed from the jars, washed thoroughly under tap water, and finally with distilled water. The plants were then transferred to propagation trays (Hummert International) with a soil mixture containing of leaf litter, loam and perlag $(1: 1: 1)$, and placed under greenhouse conditions that averaged $30{ }^{\circ} \mathrm{C}$ and with a high relative humidity ( $80 \%$ to $90 \%)$ keeping the trays covered with plastic translucent lids. and perforated weekly to decrease the relative humidity until $50 \%$ was reached. Plants then were individually repotted.

Statistical analysis. Shoot production was recorded and analyzed using a one-way analysis of variance (ANOVA) followed by a multiple comparison of means using Tukey's HSD criterion $(p \leq 0.05)$.

\section{Results and discussion}

Seed germination. Seed germination for both species started on the fifth day after being placed in culture and reached $89.8 \%$ (B. gracilis) and $95.3 \%$ (B. recurvata) after $30 \mathrm{~d}$ in culture. The development of in vitro-seedlings was similar to that observed for seed germination in soil (data not shown). Cardel et al. (1997) and Flores and 

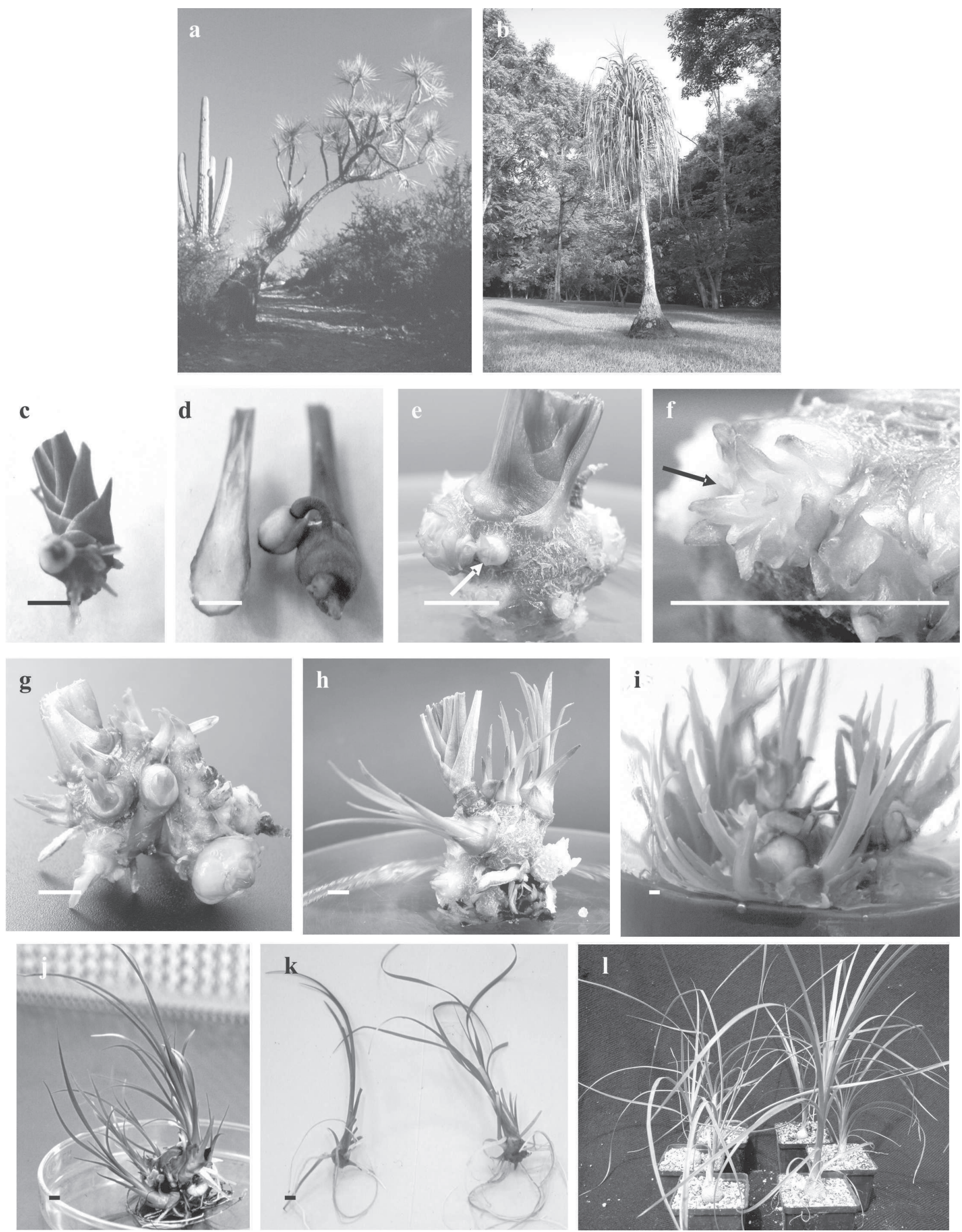

Fig. 1 (a) Adult plant of Beaucarnea gracilis. (b) Adult plant of B. recurvata. (c) In vitro germinated seedlings of ponytail used as explants. (d) In vitro germinated seedlings of ponytail dissected longitudinally and used as explants. (e) Initial phase of development of adventitious shoots, showing nodular structures (arrow). (f) Primordial buds showing the meristematic dome and primordial leaf arrangement (arrow).( g) Adventitious shoots from in vitro grown seedlings of $B$. gracilis. (h) Adventitious shoots from in vitro grown seedlings of $B$. recurvata. (i) Adventitious shoots from longitudinal section of $B$. gracilis after subculture to basal MS medium. (j) Shoots before division. (k) Rooting in $B$ gracilis (left) and $B$. recurvata (right). (l) Regenerated plantlets of $B$ gracilis (left) and $B$. recurvata (right) after 7 months in soil. Bars $=0.3 \mathrm{~cm}$. 
Briones (2001) obtained a germination rate of $95 \%$ to $100 \%$ for $B$. gracilis seeds germinated on agar and filter papers. This high germination level under controlled conditions contrasts with the low establishment of plantlets observed in the field, which can be attributed to several factors, such as soil quality, the hydric potential during the establishment season, depredation and pasturing (Cardel et al., 1997; José and Valiente-Baunet, 2001).

Induction of multiple shoots. Seedlings and longitudinal sections of seedlings of both species formed shoots in all treatments after 30 days. Most treatments produced a generalized response of adventitious shoot development mainly at the base of the explants (Fig. 1e). Regeneration was not observed from the cut areas of the seedling's longitudinal sections.

Around the tenth day of cultivation, the thickness at the explant base and the development of nodular structures was observed. On the twentieth day, the formation of small nodular protuberances was evident. Observations under the stereoscopic microscope revealed the presence of tiny buds with meristematic activity which after a few days elongated and differentiated into adventitious shoots (Fig. 1f). These shoots arose by direct organogenesis without callus formation. Generally, propagation from and several leaf primordia (primordial buds),

callus is considered unsuitable because of the risk of undesirable genetic aberrations (Feijoo and Iglesias, 1998; George, 1993).

Beaucarnea gracilis: Responding explants. The highest average number of shoots per explant was on longitudinal sections, even though the number of responding explants was lower than with seedlings (Table 1). This could have happened as a consequence of the damage caused at the moment the seedling were divided in two parts, because the $75 \%$ of explants began to oxidize during the first 2 weeks, and the $35 \%$ of them died by necrosis. There is evidence that when a cell is injured, some phenolic compound could be released into the culture medium and new compounds could be produced (Bonga and von Aderkas, 1992).

As the concentration of BA was increased the number of adventitious shoots increased. At the highest concentration of BA $(22.2 \mu \mathrm{M})$, an average of 8.2 shoots per explant were obtained from longitudinal sections of seedlings and 5.4 shoots per explant from in vitro seedlings (Table 1) (Fig. 1g). However, considerable variation among explants was observed. For example, a few explants formed as many as 20 shoots, mainly from longitudinal sections of seedlings, and two explants with only BA $(4.4 \mu \mathrm{M})$ formed one shoot at the tip of the leaf and another from the root.

Table 1. Effect of 6-benzylaminopurine concentration on shoot number, root formation and ex vitro survival from two different explants of Beaucarnea gracilis.

\begin{tabular}{|c|c|c|c|c|c|}
\hline $\mathrm{BA}(\mu \mathrm{M})$ & $\begin{array}{l}\text { Explants } \\
\text { with } \\
\text { responses } \\
\text { (no.) }\end{array}$ & $\begin{array}{c}\text { Total } \\
\text { shoots } \\
\text { (no.) }\end{array}$ & $\begin{array}{l}\text { Avg no. shoots/ } \\
\text { responding explant } \\
\pm \mathrm{SD}\end{array}$ & $\begin{array}{c}\text { Rooting } \\
(\%)\end{array}$ & $\begin{array}{c}\text { Ex vitro } \\
\text { survivaly }^{\mathrm{y}} \\
(\%)\end{array}$ \\
\hline \multicolumn{6}{|c|}{ Longitudinal sections $^{\mathrm{x}}$} \\
\hline 0 & 25 & 27 & $1.1 \pm 0.3 \mathrm{a}^{\mathrm{w}}$ & 100 & 100 \\
\hline 4.4 & 31 & 129 & $4.2 \pm 4.3 b$ & 88 & 91 \\
\hline 13.2 & 35 & 195 & $5.6 \pm 4.2 \mathrm{bc}$ & 70 & 83 \\
\hline 22.2 & 30 & 247 & $8.2 \pm 5.6 \mathrm{c}$ & 61 & 86 \\
\hline \multicolumn{6}{|c|}{ In vitro seedling ${ }^{\mathrm{v}}$} \\
\hline 0 & 40 & 40 & $1.0 \pm 0.0 \mathrm{a}$ & 76 & 100 \\
\hline 4.4 & 36 & 72 & $2.0 \pm 2.2 \mathrm{ab}$ & 77 & 90 \\
\hline 13.2 & 34 & 120 & $3.5 \pm 5.3 \mathrm{bc}$ & 64 & 87 \\
\hline 22.2 & 40 & 214 & $5.4 \pm 4.2 \mathrm{c}$ & 51 & 80 \\
\hline
\end{tabular}

${ }^{\mathrm{z}} \mathrm{N}=40$, for ANOVA only the explants with response were considered.

Results after 3 months.

'In vitro longitudinal sections of seedling.

wifferent letters within columns indicate significant difference, $P \leq 0.05$.

'In vitro seedlings with roots and tips of leaves trimmed.

Table 2. Effect of 6-benzylaminopurine concentration on shoot number, root formation and ex vitro survival from two different explants of Beaucarnea recurvata.

\begin{tabular}{|c|c|c|c|c|c|}
\hline $\mathrm{BA}(\mu \mathrm{M})$ & $\begin{array}{l}\text { Explants } \\
\text { with } \\
\text { responses }^{z} \\
\text { (no.) }\end{array}$ & $\begin{array}{l}\text { Total } \\
\text { shoots } \\
\text { (no.) }\end{array}$ & $\begin{array}{l}\text { Avg no. shoots/ } \\
\text { responding explant } \\
\pm \mathrm{SD}\end{array}$ & $\begin{array}{c}\text { Rooting } \\
(\%)\end{array}$ & $\begin{array}{c}\text { Ex vitro } \\
\text { survival }^{\mathrm{y}} \\
(\%)\end{array}$ \\
\hline \multicolumn{6}{|c|}{ Longitudinal sections $^{\mathrm{x}}$} \\
\hline 0 & 40 & 56 & $1.4 \pm 0.8 \mathrm{a}^{\mathrm{w}}$ & 100 & 96 \\
\hline 4.4 & 40 & 245 & $6.1 \pm 4.2 b$ & 96 & 100 \\
\hline 13.2 & 40 & 383 & $9.6 \pm 6.2 \mathrm{c}$ & 95 & 99 \\
\hline 22.2 & 40 & 441 & $11.1 \pm 9.2 \mathrm{c}$ & 91 & 97 \\
\hline \multicolumn{6}{|c|}{ In vitro seedling ${ }^{v}$} \\
\hline 0 & 40 & 40 & $1.0 \pm 0.0 \mathrm{a}$ & 97 & 100 \\
\hline 0 & 40 & 58 & $1.5 \pm 1.7 \mathrm{a}$ & 94 & 100 \\
\hline 4.4 & 40 & 74 & $1.9 \pm 2.4 \mathrm{a}$ & 97 & 96 \\
\hline 13.2 & 40 & 59 & $1.5 \pm 2.0 \mathrm{a}$ & 88 & 92 \\
\hline
\end{tabular}

${ }^{\mathrm{z}} \mathrm{N}=40$, for ANOVA only the explants with response were considered.

${ }^{y}$ Results after 3 months.

In vitro longitudinal sections of seedling.

${ }^{w}$ Different letters within columns indicate significant difference, $P \leq 0.05$.

vIn vitro seedlings with roots and tips of leaves trimmed.
In general, the development of the shoots was similar, using both kinds of explants, and the growth of its structures was very similar to that obtained during seed germination. In most cases, it was possible to note the swollen stem base and the growth of leaves in an alternate way. Shoots with greater size, produced an incipient arrangement of a small rosette, typical of adult individuals. In many cultures, the development of the first shoots inhibited or limited the development of subsequent shoots. This could explain the heterogeneity observed for shoot height, ranging from 0.3 to $10 \mathrm{~cm}$.

Beaucarnea recurvata. Unlike $B$. gracilis, survival was not affected by the dissection of the explants; $100 \%$ of the explants from the longitudinal sections, responded, and no oxidation was observed.

Shoots formation per explant was highest on longitudinal sections of seedlings (11.1), when $22.2 \mu \mathrm{M}$ BA was used (Fig. 1h). The use of cytokinins is common, mainly BA, to induce multiple shooting in diverse species (Hubstenberger et al., 1992; Pérez et al., 1998; Mata et al., 2001b; Moebius-Goldammer et al., 2003). Shoot formation in B. recurvata was heterogeneous, forming on some longitudinal sections up to 47 shoots. In contrast, formation of shoots was limited when using in vitro seedlings, with only 1.9 shoots per explant with $13.2 \mu \mathrm{M}$ of BA (Table 2).

As in the case of $B$. gracilis, a greater number of shoots were obtained when using longitudinal sections of seedlings as explants in compared to shoots obtained from in vitro seedlings. The size of the shoots was larger and more homogenous and vigorous in growth (Fig. 1i). This could be the result of dividing the plant and releasing the apical dominance, and the surface of the explants was in more contact with the induction medium, allowing an increase in the meristematic activity. This kind of response has been recorded in several species (Hubstenberger et al., 1992).

In both species of Beaucarnea there is a statistically significant difference between the shoot formation from longitudinal sections of seedlings and in vitro seedlings ( $p \leq 0.0001)$, i.e., from all treatments using longitudinal section of $B$. recurvata's seedlings, an average of 7.8 shoots per explant were formed. In contrast, 1.4 shoots were formed per explant from in vitro seedlings. In the case of $B$. gracilis, from all treatments using longitudinal section, 4.9 shoots per explant were formed and for in vitro seedlings 3.0 shoots per explant were formed. In both cases the highest formation of shoots was obtained by longitudinal section of seedlings in basal MS medium with $22.2 \mu \mathrm{M}$ BA, being greater in the case of $B$. recurvata. The development and growth of adventitious shoots were faster, since the shoots were evident from the first month in culture, and in the case of $B$. gracilis, the shoots were not evident until the second month in culture.

Another statistically significant difference found between the morphogenetic response of these two species was that when using seedlings as explants $(p \leq 0.0001)$, the shoot formation obtained in B. gracilis was more numerous (3.0), whereas in B. recurvata the shoot formation was 
lower (1.4), sometimes limited to the growth of the original explant.

For both species and from longitudinal sections of in vitro seedling, the highest formation of shoots was induced, for $B$. gracilis 8.2 shoots per explant were obtained (Table 1a), and for $B$. recurvata 11.1 shoots per explant were obtained (Table 2a). This data come from a half of a seedling. If we add the two parts, we could state that 16 and 22 plants can be induced from a whole seedling respectively after 6 months in culture. This report surpasses previous reports about $B$. recurvata where 1 to $2 \mathrm{~mm}$ shoot apex (from young seedlings germinated in peat), was cultured in medium Quoirin et al. with $4.4 \mu \mathrm{M}$ $\mathrm{BA}$, where three to four plants per explant can be produced after 9 months in culture (Mekers, 1988; Samyn, 1993).

Rooting. When shoots were 5 to $10 \mathrm{~cm}$ in height they were individualized to induce root formation. In a few cases, the explants started to develop roots, even before being individualized (Fig. 1j). Some shoots, from both species, continued shoot proliferation, possibly as a result of buds that remained inactive from the apical dominance exerted by the taller shoots. This result was observed mainly from $15 \%$ to $30 \%$ shoots that originated from longitudinal sections of seedlings, initially cultured on high concentrations of BA (13.2 and $22.2 \mu \mathrm{M})$. In those cases, the majority of explants continued forming from one to threenew shoots. It has been found that the exogenous levels of cytokinin influence the endogenous auxin to cytokinin ratio and therefore some species maintain a continued capacity to form new shoots even in cultured medium without plant growth regulators (George, 1993).

Rooting of $B$. gracilis shoots from both kinds of explants was influenced by the induction medium, i.e., the rooting percentage diminished in inverse proportion to BA concentration (Table 1).

In shoots of root formation was obtained between the first and the fourth week when shoots were cultured en MS medium with activated charcoal $\left(1 \mathrm{~g} \cdot \mathrm{L}^{-1}\right)$. One to four vigorous roots were formed (Fig. 1k), similar to those obtained from in vitro seed germination. At the end of the rooting period ( 2 months), most of the roots had formed secondary roots. Samyn (1993) reported that $B$. recurvata rooting occurred easily on one-third-strength MS medium without growth regulators, but the number of roots was increased by NAA $(0.67$ and $1.35 \mu \mathrm{M})$ and the in vitro root initiation occurred in 2 weeks.

In general, the rooting percentage of $B$. gracilis was $80 \%$ to $100 \%$. For $B$. recurvata, the rooting percentage was higher than $90 \%$ except for shoots induced on $22.2 \mu \mathrm{M}$ BA where the percentage was $88 \%$ (Table 1 and 2). Hubstenberger et al. (1992) found that MS medium was appropriate for rooting cactus and other CAM species. Others also report spontaneous rooting in a medium free of exogenous auxins (Ault and Blackmon, 1987; Escobar et al., 1986; Li et al., 2002; Martín and Pérez, 1995).

Given the aforementioned results, there is a correlation between rooting in vivo and the treatments required in vitro; the species which root freely in vivo, as Beaucarnea species, also root spontaneously in a medium without growth regulators (Hubstenberger et al., 1992).

Ex vitro survival. Most of the plants that formed roots in vitro and potted in soil survived and continued their development (Fig. 11). The survival percentage for $B$. gracilis was $80 \%$ to $100 \%$, and for $B$. recurvata $92 \%$ to $100 \%$ (Tables 1 and 2). Plantlets that did not root in vitro survived with a percentage higher than $50 \%$ (data not shown). The plantlets developed a swollen stem base and one shoot apex from the base after seven months, as in the case of the seedlings obtained from seed germination in soil.

The over-collection of young and adult plants of these species affects not only the population size but also the sex proportion, because they are dioecious species. The fertility possibly decreases and hence the seed production, which can lead to the risk of extinction through the reduction of the minimal viable size of the population. The micropropagation of plants by means of direct organogenesis will not only contribute to satisfy the demand in the horticultural market, but also to design reintroduction programs in the wild, contributing to the conservation of these endangered species.

\section{Literature Cited}

Ault, J.R., and W.J. Blackmon. 1987. In vitro propagation of Ferocactus acanthodes (Cactaceae). HortScience 22(1):126-127.

Bonga, J.M. and von P. Aderkas. 1992. In vitro culture of trees. Kluwer Academic Publ., The Netherlands.

Cardel, Y., V. Rico-Grey, J. García-Franco, and B.L. Thien. 1997. Ecological status of Beaucarneagracilis, an endemic species of the semiarid Tehuacán Valley, México. Conserv. Biol. 11(2):367-374.

Carneiro, L.A., R.F.G.Araújo, J.G.M.Brito, M.H.P.B. Fonseca, A. Costa, O.J Crocomo, and E. Mansur. 1999. In vitro regeneration from leaf explants of Neoregelia cruenta (R.Graham) L.B. Smith, an endemic bromeliad from eastern Brazil. Plant Cell Tiss. Organ Cult. 55:79-83.

Eguiarte, E.L., M.R. Duvall, G.H. Learn, and M.T. Clegg. 1994. The systematic status of the Agavaceae and Nolinaceae and related Asparagales in the Monocotyledons: An analysis based on the rbcL gene sequence. Bol. Soc. Bot. Méx. 54:35-56.

Escobar,H.A., V.M Villalobos, andA. Villegas. 1986. Opuntia micropopagation by axillary proliferation. Plant Cell Tiss. Organ Cult. 7:269-277.

Fay, F.M. 1994. In what situations is in vitro culture appropriate to plant conservation? Biodiv. Conserv. 3:176-183.

Feijoo, M. and I. Iglesias. 1998. Multiplication of an endangered plant: Gentiana lutea L. subsp. aurantiaca Lainz, using in vitro culture. Plant Tiss. Cult. Biotechnol. 4(2):87-94.

Flores, J. and O. Briones. 2001. Plant life-form and germination in a Mexican inter-tropical desert: effects of soil water potential and temperature. J. Arid Environ. 47:485-497.

Franco, M.I. 1995. Conservación in situ y ex situ de las agaváceas y nolináceas mexicanas. Bol. Soc. Bot. Méx. 57:27-36.

George, E.F. 1993. Plant propagation by tissue culture. Exegetics Limited, England.

González-Benito, E., C. Martín, J.M. Iriondo, and C. Pérez. 1999. Conservation of the rare and endangered plants endemic to Spain, p. 251-264. In: E. Benson (ed.). Plant conservation biotechnology. Taylor and Franis Ltd., London.

Hernández, L. 1993a. Beaucarnea ¿Un género amenazado? Cact. Suc. Mex.. 38:11-13.
Hernández, L. 1993b. Cladistic analysis of the American genera of Aspararagales and the systematic study of Beaucarnea (Nolinaceae) and Hemiphylacus (Hyacinthaceae). PhD diss. Univ. Texas, Austin.

Hubstenberger, J.F., P.W. Clayton, and G.C Phillips.1992. Micropropagation of cacti(Cactaceae), p. 49-68. In: Y.P.S. Bajaj (ed.). Biotechnology in agriculture and forestry. vol. 20, High-tech and micropropagation IV. Springer-Verlag, Berlin: Heidelberg.

José, J.R. and A. Valiente-Banuet. 2001. Umbrales de germinación de Beaucarnea gracilis. Resumen 491, XV Congreso Soc. Bot. Méx. (Ecología).

Li, W., H. Gao, R. Lu, G. Guo, and G. Zheng. 2002. Direct plantlet regeneration from the tuber of Stachys sieboldii. Plant Cell. Tiss. Organ Cult. 72:259-262.

Martín, C. and C. Pérez. 1995. Micropropagation of five endemic species of Limonium from the Iberian peninsula. J. Hort. Sci. 70(1):97-103.

Martínez-Vázquez, O. and A. Rubluo.1989. In vitro mass propagation of the near-extinct Mammillaria san-angelensis Sánchez-Mejorada. J. Hort. Sci. 64(1):99-105.

Mata, M.R., V.M. Chávez, and R. Bye. 2001a. In vitro regeneration of plantlets from zygotic embryos of Picea chihuahuana Martínez, an endemic Mexican endangered species. In Vitro Cell. Dev. Biol.-Plant 37:73-78.

Mata, R.M., R.M. Monroy, G.K. Moebius, and V.M. Chávez 2001b. Micropropagation of Turbinicarpus laui Glass et Foster, an endemic and endangered species. In Vitro Cell. Dev. Biol. Plant 37:400-404.

Mauseth, J.D. 1979. A new method for the propagation of cacti: sterile culture of axillary buds. Cact. Succ. J. (U. S.) 51:186-187.

Mekers, O. 1988. Beaucarnea recurvata, an ultravigorous room plant, which can be propagated in vitro. Verbondsnieuws voor de Belgische Sierteelt 32(5):16-17.

Moebius-Goldammer, K.G., M. Mata-Rosas and V.M. Chávez. 2003. Organogenesis and somatic embryogenesis in Ariocarpus kotschoubeyanus (Lem.) K. Schum. (Cactaceae), an endemic and endangered Mexican species. In Vitro Cell. Dev. Biol. Plant 39(4):388-393.

Murashige, T. and F. Skoog, 1962. A revised medium for rapid growth and bioassays with tobacco tissue cultures. Phisiol. Plant. 15:473-497.

Pérez, E.M.B., M.E. Pérez, E. Villalobos, E. Meza, L.R. Morones, and H.J. Lizalde. 1998. Micropropagación of 21 species of Mexican cacti by axillary proliferation. In Vitro Cell. Dev. Biol. Plant 34:131-135.

Rodríguez-Garay, B. and A. Rubluo. 1992. In vitro morphogenetic responses of the endangered cactus Aztekium ritteri (Boedeker). Cact. Succ. J. (U.S.) 64:116-119.

Samyn, G.L. 1993. In vitro propagation of ponytail palm: Producing multiple-shoot plants. HortScience 28(3):22.

Samyn, G.L. 1997. Micropropagation of Beaucarnea recurvata Lem. Syn. Nolina recurvata (Lem.) Hemmsl. (ponytail palm), p. 264-275. In: Y.P.S. Bajaj (ed.). Biotechnology in agriculture and forestry. vol 4. High-tech and micropropagation. VI. Springer-Verlag, Berlin Heldelberg.

Semarnat, 2002. Norma Oficial Mexicana NOM059-ECOL-2001, Protección ambiental-Especies nativas de México de flora y fauna silvestresCategorías de riesgo y especificaciones para su inclusión, exclusión o cambio-Lista de especies en riesgo. Diario Oficial de la Federación (6 de Marzo 2002):1-81.

Stuppy, W. and W. Nagl. 1992. Regeneration and propagation of Ariocarpus retusus Scheidw. (Cactaceae) via somatic embryogenesis. Bradleya 10:85-88. 